\title{
Kansatiede ja tulevaisuudentutkimus - molempi parempi
}

Jussi LeHtonen: Skenaarioita maaseudun palveluista - kaupat, kirjastot ja postit historiasta tulevaisuuksiin. Turun yliopiston julkaisuja, sarja C, osa 429. Scripta Lingua Fennica Edita, Turku 2016. 323 s., 12 liites.

Ajan ulottuvuuksista - menneisyys, nykyisyys, tulevaisuus - yksi on ylitse muiden. Me ihmiset olemme vahvasti tulevaisuuteen orientoituneita. Teemme asioita vaikuttaaksemme tulevaisuuteen, ja tietoisuutemme on lähtökohtaisesti odotuksien värittämää. Arkielämän tulevaisuudenhallinta on monesti niin rutiininomaista, ettei sitä edes huomaa. Aamulla pukeudumme lämpimästi suojautuaksemme kylmältä tai pukeudumme tavanomaisen rennosti työpaikan pukukoodin mukaisesti. Viemme lapset päivähoitoon hakeaksemme heidät iltapäivällä kotiin ja lainaamme kotimatkalla kirjastosta uuden iltasatukirjan. Optimaalista tulevaisuuden suunnittelua, ennakointia ja riskienhallintaa.

Akateeminen tulevaisuudentutkimus on ottanut yhdeksi asiakseen tulevaisuutta koskevien intuitioiden jalostamisen ja systematisoinnin, tavoitteena rakentaa monitieteistä tutkimusparadigmaa, jonka avulla erilaisia tulevaisuuksia voidaan hahmottaa ja niiden toteutumiseen vaikuttaa. Tulevaisuudentutkimus hyödyntää estoitta erilaisten perinteisten tieteenalojen, kuten taloustieteen, sosiologian, operaatiotutkimuksen, systeemiteorian ja kulttuurintutkimuksen, työkaluja saadakseen paremman kuvan tulevaisuuksien kirjosta ja dynamiikasta. Tyypillisesti tässä tieteenalojen kombinaatiossa ja ristiinhyödyntämisessä voittavat molemmat osapuolet: saamme parempaa tulevaisuudentutkimusta ja tieteenalan X tulevaisuusorientaatio vahvistuu.

Näin on tilanne Jussi Lehtosen kansatieteen väitöskirjassa, jossa yhdistetään tulevaisuudentutkimusta ja kansatiedettä - molemmat voittavat. Tulevaisuudentutkimus on monin osin keskittynyt vallanpitäjien ja päätöksentekijöiden tulevaisuuskuvien luotaamiseen, mutta kansatieteen avulla saadaan kulttuurinen diversiteetti ja ehkä myös "kansan" ääni kuuluviin. Kansatiede on puolestaan ollut paljolti menneisyyksien luotaamista, joten tulevaisuudentutkimuksen intressin ja työvälineiden käyttöönotto monipuolistaa ja syventää kansatieteen tutkimusparadigmaa.

Erityisesti erilaiset tulevaisuuspolut ja niitä kehystävät maailmankuvalliset elementit aukeavat kansatieteen ja muiden kulttuurintutkimuksen tieteenalojen työkaluilla paremmin kuin yksinomaan esimerkiksi kauppatieteen tai teknologiatutkimuksen varaan ankkuroituvan tulevaisuudentutkimuksen välineistöllä. Kansatiede kulttuurintutkimuksen ydinalueena tuo esille ihmisen ja yhteiskunnan kulttuurisuuden, sen miten tulevaisuuden mahdollisuudet ja niitä koskevat odotukset ovat vuorovaikutuksessa neuvoteltuja asioita ja miten ihmiset suunnistavat mahdollisten maailmojen verkostoissa kulttuuristen resurssien avulla.

Tulevaisuuteen vaikuttaminen ei ole sekään kansatieteelle vierasta. Kansatiede on muiden ihmistieteiden tapaan tarvittaessa radikaali muutosvoima. Alueellisen identiteetin, kaupunginosan, maaseudun tai kulttuuriperinnön tutkimus voi nostaa esille muutoksen ja säilyttämisen voimia, vahvistaa (yleensä) tai heikentää (harvemmin) ihmisten ja yhteisöjen kulttuurisia identiteettejä. Mielikuva kansatieteestä rukinlapojen tai hirsisalvosten taksonomiana on jo aikansa 
elänyt, ja moderni kansatiede on täysiveristä kulttuurintutkimusta, joka ulottaa otettaan menneestä nykyisyyteen ja tulevaisuuteen.

Jussi Lehtosen väitösprojektin tutkimuskohteena ovat valitut maaseudun palvelut, joiden historiaa, nykytilannetta ja erityisesti tulevaisuuksia tutkimuksessa valotetaan. Erilaisten palvelujen tulevaisuuspolkuja jäsennetään aina 2040-luvulle ulottuvien skenaarioiden avulla. Keskeisenä ratkaisuna maaseudun palvelujen järjestämiseen ovat mobiilipalvelut, kirjaimellisesti, eli pyörillä kulkevat myymäläautot, kirjastoautot, postiautot tai monipalveluautot. Skenaarioita rakennetaan asiantuntijoiden delfoi-paneelilla, mutta kuva täydentyy perinteisillä palveluja koskevilla kyselyillä ja teemahaastatteluilla, joissa asiantuntijoiden skenarointi kontekstualisoituu historiaan ja nykytilanteen kenttään.

Lehtosen työ on kiinnostava paitsi perustutkimuksena maaseudun palveluista ja kokeiluna kansatieteen ja tulevaisuudentutkimuksen yhdistämisestä myös soveltavana tutkimuksena ja kehitystyöprojektina, jossa luodaan työkaluja maaseudun palveluiden rakentamiseen. Näiltä osin työ jää hiukan vajaaksi - siinä olisi voinut olla oma yhteenvetolukunsa päätöksentekijälle: näin tehdään parempaa maailmaa. Tutkimukseen osallistuneet maaseudun ihmiset ja erityisesti delfoi-paneeliin osallistuneet asiantuntijat ovat toki osallistumisen myötä aktivoituneet ajattelemaan maaseudun palveluita ja mahdollisesti motivoituneet tekemään ratkaisuja tai aloitteita erilaisten palvelujen kehittämiseksi. Ehkä tämä tuotekehittelyosuus toteutuu, kun Lehtonen matkaa tulevaisuuteen. Kattavaa väitöskirjaprojektia kannattaa tuotteistaa erilaisia sidosryhmiä varten, kuten me humanistitkin jo nykyään tiedämme.

Vaikka suomalaiset kansatieteilijät muutamaa poikkeusta lukuun ottamatta ovat pysyneet erossa tulevaisuudentutkimuksesta, ei tutkimusasetelma sellaisenaan ole niin harvinainen kuin Lehtonen antaa olettaa. Soveltavassa kansatieteessä, antropologiassa, kehitystutkimuksessa, sosiologiassa, sosiaalipolitiikassa, aluetieteessä, organisaatiotutkimuksessa ja kasvatustieteessä meillä ja eritoten muualla - on tutkimusasetelmia, joissa kulttuurintutkimuksellinen ihmistutkimus yhdistyy tulevaisuuksien luotaamiseen ja optimaalisten tulevaisuuksien tekemiseen. Lehtosen väitöskirjan lähdeluettelo onkin turhan kotimainen, vaikka aiheen puolesta pitäisi ankkuroitua globaalisti.

Väitöskirja on kielellisesti ja ulkoasultaan tinkimättömän huoliteltu. Monipuolinen kuvitus alkaen aina kannen ruostuneesta (myymälä?)autonpyörästä sekä lukuja kehystävät etnokronografiset sitaatit ("sateen jälkeen paistaa aina aurinko") ilahduttavat lukijaa.

Kokonaisuutena Jussi Lehtosen väitöskirja toimii hyvänä esimerkkinä kansatieteen monipuolistamisesta. Se rohkaisee nuorempia kulttuurintutkijoita ajattelemaan tutkimusasetelmia uudella tavalla sekä myös näkemään kansatieteen arvon soveltavassa tutkimuksessa ja kehitystyössä.

MatTi KampPinen

matti.kamppinen@utu.fi

Uskontotiede, 20014 Turun yliopisto 